\title{
Postmortem cadaveric depredation by animals- A diagnostic dilemma
}

\author{
Ashish Tyagi ${ }^{1, *}$, Shashank Tyagi ${ }^{2}$, Nishtha Malik ${ }^{3}$, Hitesh Chawla ${ }^{4}$ \\ ${ }^{\mathbf{1}}$ Assistant Professor, ${ }^{4}$ Associate Professor, SHKM Govt. Medical College, Nuh, ${ }^{2}$ Assistant Professor, Dept. of Forensic \\ Medicine, HBT Medical College \& RN Cooper Hospital, Mumbai, Maharashtra, ${ }^{3}$ Resident, Dept. of Microbiology, GMC, \\ Amritsar, Punjab
}

*Corresponding Author:

Email: djashtyg@yahoo.com,djashtag96@gmail.com

\begin{abstract}
Post-mortem animal predation may sometimes confuse at first sight with injuries of crucial origin, thus arousing suspicion of ante-mortem external violence. A reliable differentiation of the origin of such uncertain injuries is of vital importance, a fact that is mainly true for the investigation of suspected homicide and/or man made body mutilation after death. In forensic pathology, the identification of injuries caused by animals as post-mortem artefact is usually done by forensic pathologists with vast practical experience and special knowledge of the appearance and morphology of tooth marks of carnivores and rodents, respectively. Meticulous examination can only help to differentiate the cut in bones by sharp weapons or sawing of long bones by sharp weapons, for surgical amputation, from gnawing of dead bones by wild animals, showing no ante-mortem reaction. Here, we present a case report of a young adult male individual, who was found dead on railway tracks with alleged history of railway accident and all the facial features distorted by animal scavengers resulting in difficulty in identification, injury differentiation $\&$ cause and manner of death.
\end{abstract}

Keywords: Artefact, post-mortem, Scavenging, Depredation, Animals, Injuries, Mutilation.

\section{Introduction}

Dorland's Illustrated Medical Dictionary defines an artefact as any artificial product, any structure or feature that is not natural, but has been altered by processing. In Forensic Pathology, the artefact is any change caused or a feature introduced into a body after the death that is likely to lead to misinterpretation or medicolegally significant antemortem findings. ${ }^{(1)}$ Mutilation is an act of physical injury that degrades the appearance or function of any living body, sometimes causing death. Mutilation of a body could be intentional or unintentional during life or after death for mainly destroying the identity. (2)

The body parts are not only mutilated but also the identity data can be deliberately destroyed in cases when the dead body get mutilated by dogs, jackals, vultures, rats, vermins etc. especially when left exposed in open places, to the extent of non recognition of body features or skeletonisation. ${ }^{(3)}$ Animal predation is a part of natural food chain. They usually attack the exposed body parts and particularly those soaked with blood or human fluids due to injuries or otherwise; and thus eat away the soft tissues resulting into skeletonization of the body sometimes even in less than 24 hours. The animal activity may even alter ante-mortem injuries. ${ }^{(2)}$ Postmortem predation creates injuries that arouse suspicions of homicide. Large defects on the face, neck, and torso with variable loss of viscera and bony injury are observed following predation by large pets e.g., dog. ${ }^{(4)}$ Examiners should pay careful attention to wound edges, particularly the possibility of animal tooth marks left on cartilage or bone. ${ }^{(5)}$ Animal scavenging creates difficulties with the interpretation of various medicolegal questions such as identity of the victim and cause of death and, as a consequence, criminal charges against the perpetrator cannot be framed or proven. ${ }^{(6)}$

\section{Case Report}

A dead body of a young adult male individual was brought by Railway police, which was found near railway tracks with alleged history of railway accident. The deceased was a chronic alcoholic. On one day of March, 2013 he went away from his home to a place which was $60 \mathrm{kms}$ away by train, but couldn't reach home next day. After looking for the person for two days the relatives received information from the railway police that they have found an unclaimed dead body on the tracks and also recovered a phone number from his wallet by which they have traced them. The dead body was beyond recognition, but it was identified on the basis of belongings; and was presumed that he had died because of railway accident. Investigating officer also thought of the same as no other appreciable injury was noticed over the body except the mutilation of face suspecting due to animals - dogs bites etc. The body was taken to a peripheral hospital for post-mortem examination. After observing the mutilation of parts of face, neck, scalp the board of doctors referred this body to our department for expert opinion.

Post-mortem Examination: The brought dead body showed early changes of decomposition with peeling of epidermis and marbling. The facial features were distorted and were not identifiable. The skin, soft tissues were missing over major part of face. The underlying facial bones showed multiple fractures of all bones including mandible. The forehead, along with skin and soft tissues around the jaw line were spared. The remnant adjacent skin and soft tissues around right 
side of face showed deep underlying ecchymoses with crushed ragged margins and forehead was smudged with dried blood (Fig. 2). No external injuries were present over the scalp. On dissection, the scalp was found ecchymosed on occipital region with comminuted fracture seen over base of skull in the anterior and middle fossa; and the subdural and subarachnoid haemorrhages were well appreciated over both cerebral hemispheres. The skin over the neck showed superficial bite marks (Fig. 3), claw scratch marks with serrated edges and laceration present over the left supraorbital region. All the visceral organs were pale (Fig. 1/d). The scratch abrasions present over both sides of neck were multiple, parallel to each other and have serrated edges (Fig. 1). There were grease marks and blackening present over the clothes. Apart from some abrasions present over the lower limbs, no other injuries present over the body.

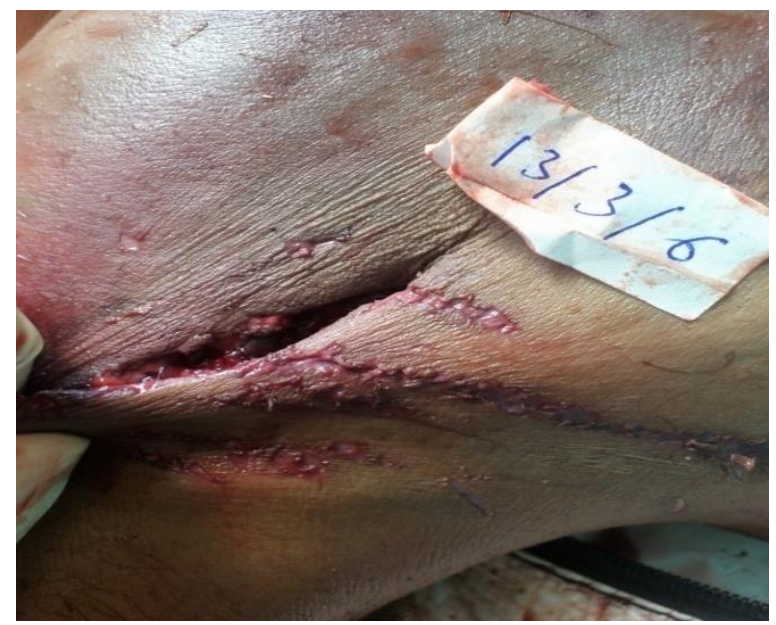

Fig. 1: Showing multiple parallel scratch marks over neck by claws or nails

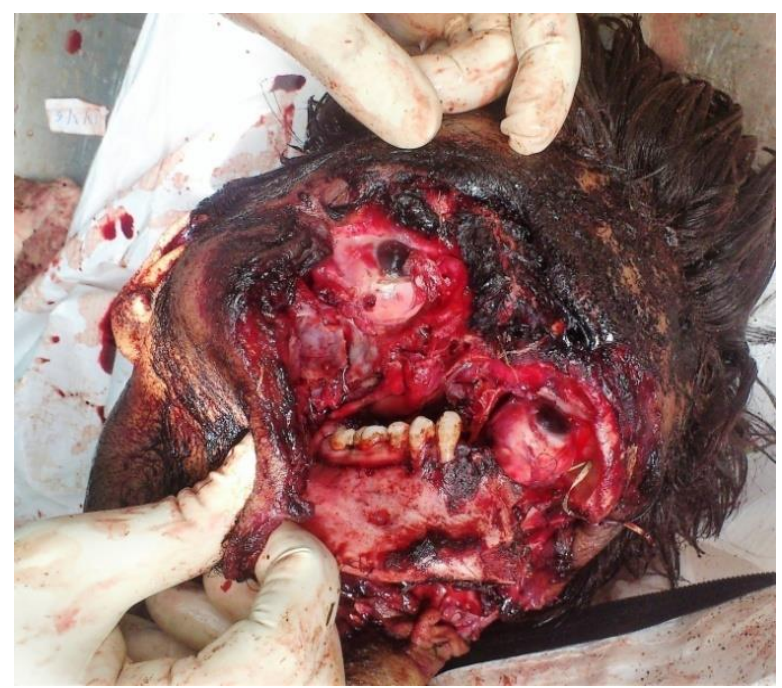

Fig. 2: Showing mutilation of face with antemortem injuries present over right side of face and forehead and fracture facial bones with gnawed adjoining tags of skin and soft tissues

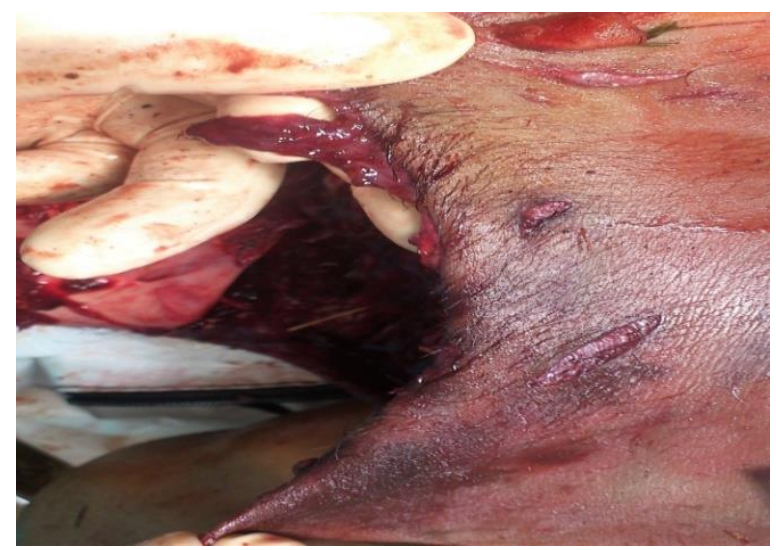

Fig. 3: Showing teeth marks over the skin of neck

After the external examination, viscera were preserved for chemical analysis and the report of which came out to be positive for ethyl alcohol.

After conducting the post-mortem examination on the basis of these findings, we concluded that the cause of death in this case was cranio-cerebro-facial damages as a result of ante-mortem head injury consequent upon hard and blunt force / surface impact.

\section{Discussion}

Mutilation of a dead body is not always the act of a criminal who wants to destroy all traces of identity and thus to get greater facilities for its disposal. In India, animals and birds, may attack a dead body and mutilate it in a very short time, when exposed in an open field on the outskirts of a village or a town. Besides, it is not an uncommon sight to notice the dead bodies of lunatics, fakirs and pilgrims, lying on the roadside or on remote places and being attacked by these animals. ${ }^{(7)}$

However, any animal attacking the dead body will primarily select those areas where the skin is broken; thus it is not uncommon to find that antemortem wounds have been enlarged to a great degree by postmortem invaders. ${ }^{(8)}$ In case of larger animals like dogs, rats, the destruction of exposed skin areas is usually more dramatic. Often those portions most accessible from the ground, i.e. the face and neck in the recumbent body, are involved. ${ }^{(9)}$

Rodents gnaw away tissues over localised areas, which are usually circular or wedge shaped, with finely serrated margins, showing irregular edges by nibbling and leave long grooves. The bites by dogs are clear cut, with deep impressions of teeth in small area. Individual punctures may resemble stab wounds. The cat bites are usually very small and round. Face and neck are usually involved in the recumbent body. They may sometimes resemble knife wounds, especially bones. ${ }^{(8)}$

Post-mortem animal depredation, especially by dogs is not an uncommon phenomenon in forensic autopsy practice, ${ }^{(10)}$ and it is obligatory to differentiate between fatal dog bite injuries and post-mortem dog bite pattern at autopsy. ${ }^{(11)}$ In fatal dog attacks, no

International Journal of Forensic Medicine and Toxicological Sciences, October-December, 2016:1(1):20-23 21 
specific injury site is evident, and the clothes might be rumpled, shifted or torn apart. On the other hand, damage patterns in cases of post-mortem dog predation are generally limited to a circumscribed and usually unclothed body area such as head and neck or the hands. ${ }^{(13-16)}$ If clothes are opened or missing, the genital organs or other body sites may also be affected, ${ }^{(17-19)}$ which might raise suspicion of homicide or a sexually motivated crime. ${ }^{(20-22)}$ Clothed body parts usually remain unaltered; post-mortem dog bites seldom involve torn dresses. ${ }^{(19,22)}$

Dog bite injuries involve typical broad soft tissue defects with irregular partially curved wound margins as well as canine tooth punctures. Parallel skin scratches may represent claw marks. ${ }^{(15,25,26)}$ The head and hands are often subject to post-mortem animal depredation, since these body regions are usually unclothed and thus easily accessible; bony defects are also possible. ${ }^{(14-16,24)}$ Other injury patterns such as opened body cavities or genital tissue defects are unusual. ${ }^{(17-19,22,23)}$ In most cases, such injuries should not be difficult to identify as post-mortem animal depredation patterns at autopsy: the absence of vital signs (e.g., subcutaneous tissue bleeding, signs of exsanguinations, blood aspiration) makes it easy to distinguish post-mortem dog bite injuries from fatal dog bite wounds. ${ }^{(12,19,21)}$

\section{Conclusion}

Wrong observation, erroneous interpretation and injudicious conclusion of an autopsy surgeon in respect of such important though deceptive findings like postmortem artefacts may often lead to imprisonment of the innocent or freedom of the accused much against the principle of natural justice and the doctor himself often facing tough and critical cross examination in the court of trial. Misinterpretation may lead to wrong cause and manner of death and miscarriage of justice. Many a times, animals contribute to problems in post-mortem evaluation and identification of injuries by removing tissues and organs, modifying or destroying existing lesions, and causing widespread tissue damage. This case report mentioned similar kind of artefact i.e. post-mortem animal activity that may be found during autopsy and cause potential diagnostic problems in ascertaining the cause of death, manner of death, time since death, identification of deceased etc.

\section{References}

1. Dikshit P C. Textbook of Forensic medicine and Toxicology. 2nd ed. Pee Pee publishers and distributors (P) Ltd: Delhi; 2007. p. 147.

2. Sirohiwal BL, Chawla H, Paliwal PK. Mutilation of Human Dead Body without Mutilating the Cause of Death - Study of two case reports. Anil Aggrawal's Internet Journal of Forensic Medicine and Toxicology [serial online], 2014; Vol. 15, No. 1 (JanJune 2014): [about 5 p]. Available from: http://anilaggra wal.com/ij/vol_015_no_001/papers/paper003.html.
3. Karmakar RN, editor. J.B. Mukharjee's Forensic Medicine and Toxicology. $4^{\text {th }}$ ed. Academic publishers: Kolkata; 2007.p.201-3,2014

4. Forensic Pathology of Trauma, Shkrum M J., Ramsay DA. Humana Press. Totowa, New Jersey. 2007. P 57-8.

5. Forensic Pathology Principles and Practice. Dolinak D, Matshes EW. Lew EO. Elsevier. London. 2005 p. 548-50.

6. An autopsy study on medico-legal evaluation of postmortem scavenging. Jani CB, Gupta BD. Med Sci Law. 2004 Apr;44(2):121-6.

7. Rao NG. Textbook of forensic medicine and toxicology. $2^{\text {nd }}$ ed. Jaypee Brothers Medical Publishers (P) Ltd. 2010 p. 185-7.

8. Reddy K S N. The essentials of forensic medicine and toxicology. $30^{\text {th }}$ ed. Hyderabad: $2011 ;$ p.431.

9. Spitz WU, Fisher RS. Medicolegal investigation of death. Charles C Thomas. Springfield USA. 1973. Second Printing. p. 29.

10. Reuhl J, Urban R, Bratzke H, Willnat M. To“dliche Hundebisseim Sektionsgut rechtsmedizinischer Institute. Ergebnisseeiner Fragebogenaktion. Rechtsmedizin. 2001;11:411.

11. De Munnynck K, Van de Voorde W. Forensic approach of fatal dog attacks: a case report and literature review. Int J Legal Med. 2002;116:295-300.

12. Tsokos M, Byard RW, Püschel K. Extensive and mutilating craniofacial trauma involving defleshing and decapitation. Am J Forensic Med Pathol. 2007;28:131-6.

13. Hayase T, Yamamoto K, Yamamoto Y. An unusual case of extensive cadaver ingestion by a domestic dog. Arch Kriminol. 1994;194:177-81.

14. Po"tsch-Schneider L, Endris R. Postmortale Hundebißspuren und Leichenfraß. Kriminalistik. 1984;8:351-3.

15. Rossi ML, Shahrom AW, Chapman RC, Vanezis P. Postmortem injuries by indoor pets. Am J Forensic Med Pathol. 1994;15: 105-9.

16. Buschmann C, Wrobel D, Tsokos M. Post-mortem animal depredation of the genital region caused by a half-breed dog. Arch Kriminol. 2008;222:182-6.

17. Tsokos M, Koops E, Pu"schel K. Post-mortem dog bites after sexually motivated homicide with multiple stab wounds-differential diagnostic aspects. Arch Kriminol. 2000;206:30-7.

18. Weiler G. Cadaver destruction through dog- and lion bites. Arch Kriminol. 1978;162:108-14.

19. Grellner W, Meyer E, Fechner G. Simulation of attempted homicide by dog bite in unconscious state. Arch Kriminol. 1998;201:165-71.

20. Ma"tzsch T, Kleiber M. Simulation of a sexual crime through the effects of animals. Arch Kriminol. 1979;164:78-82.

21. Mortinger H, Missliwetz J. Forensically important penis injuries. Beitr Gerichtl Med. 1989;47:619-23.

22. Luff K. Tod durch Hundebisse oder postmortale Zerfleischung? Dtsch Z Ges Gerichtl Med. 1955;44:2048 .

23. Mittmeyer HJ, Staak HJ, Kraemer R. Wound pattern and identification problems in dog bites. Arch Kriminol. 1976;157:172-8.

24. Schumann M, Nolte I, Huckenbeck W, Barz J. Postmortem animal injury-a few hours after death? Rechtsmedizin. 1996;7:22-4.

25. Rothschild MA, Karger B. Postmortaler Tierfraß durch Wirbeltiere. In: Brinkmann B, Madea B, editors. Handbuch gerichtliche Medizin 1. Berlin/Heidelberg/ New York: Springer; 2004. p. 187-91. 
26. Schmeling A, Schmidt S, Hartwig S, Geserick G. Decapitation due to early post-mortem canine gnawing. Arch Kriminol. 2004;214:86-92. 